\title{
Metastatic spindle cell melanoma on cytology - a diagnostic challenge
}

\section{Archana Shivamurthy', Ranjini Kudva², Annappa Kudva², Padmapriya Jaiprakash²}

${ }^{1}$ Department of Pathology, Melaka Manipal Medical College, Manipal University, Manipal, India, ${ }^{2}$ Department of Pathology, Kasturba Medical College, Manipal, Manipal University, Manipal, India, ${ }^{3}$ Department of Surgery, Kasturba Medical college, Manipal University, Manipal, India

Corresponding author: Dr. Archana Shivamurthy, E-mail: archana_018@yahoo.co.in

\begin{abstract}
Spindle cell melanoma is a rare variant of malignant melanoma. The diagnosis on fine needle aspiration cytology can be challenging. An accurate cytological diagnosis is important owing to the prognostic and therapeutic implications. It also directs staging, treatment and prognosis. Spindle cell melanoma may mimic other spindle cell lesions because Due to the lack of characteristic features of conventional melanoma, spindle cell melanoma can be often mistake for various other spindle cell lesions. Fine needle aspiration cytology is often used to document recurrent or metastatic disease and thus plays a very important role. We present a case of a 6lyear old male with spindle cell melanoma.
\end{abstract}

Key words: Melanoma; Spindle cell; Desmoplastic; Cytology

\section{INTRODUCTION}

Spindle cell melanoma is a rare variant of malignant melanoma and the diagnosis on fine needle aspiration cytology (FNAC) can be extremely difficult $[1,2]$. An accurate cytological diagnosis is important owing to the prognostic and therapeutic implications. It also directs staging, treatment and prognosis. The incidence of spindle cell melanoma varies from 3\%$14 \%$. Spindle cell melanoma can occur anywhere on the body. Typically, it often presents with widespread metastatic disease $[2,3]$. However some melanomas may present as a metastasis of unknown primary origin while others may take several decades to develop metastasis [4].

\section{CASE REPORT}

A 61 year old male came with a history of a mole over the right foot since 4 months. It was insidious in onset and rapidly progressive in size. He had also noticed a swelling in the right thigh. There was no history of fever or chills, loss of weight or appetite. On examination there was a greyish plaque present over the right foot and right inguinal lymphadenopathy. Ultrasonography of the abdomen revealed few enlarged right external iliac lymphnodes and right inguinal lymphnodes. FNAC of the inguinal node was done, followed by wide local excision of the lesion over the right foot followed by right inguinal block dissection.

FNA smears showed clusters \& fascicles of spindle cells with slender elongated nuclei and scant cytoplasm, in a background of macrophages, lymphocytes few neutrophils and necrosis. The nuclei displayed a bland morphology. Occasional cells showed mild pleomophism. Macronucleoli and melanin pigment were absent (Fig. 1 and 2). A diagnosis of spindle cell lesion was rendered and in view of the history, a possibility of metastatic spindle cell melanoma was suggested. Grossly, the wide local excision biopsy specimen showed a surface ulcer measuring $2.5 \mathrm{x}$ $2 \mathrm{~cm}$ and the cut section showing grey brown areas. 18 lymphnodes were isolated from the right inguinal block dissection specimen. A diagnosis of spindle cell variant of malignant melanoma (Clarks level IV) with

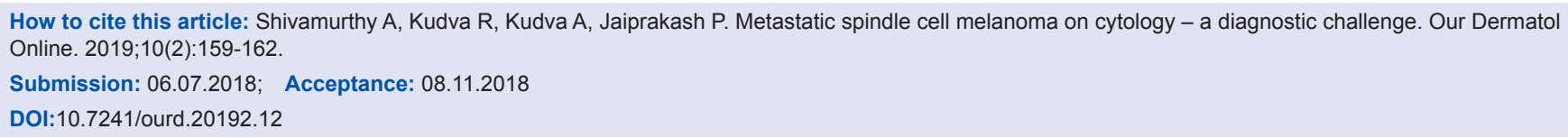


lymph node metastasis was finally rendered (Figs. 3 and 4). Radiation oncology consultation was sought and the patient was advised computerized tomography of thorax, abdomen and pelvis.

\section{DISCUSSION}

Cytological features of spindle cell melanoma include predominantly dyscohesive spindle cell cluster, interlacing fascicles and whorls of slender spindle cells with illdefined cell borders, variable amount of cytoplasm, often showing bipolar long cytoplasmic projections which may have curved or twisted ends [5-7]. The presence of epitheloid cells has also been noted, few of which display classical cytological features of conventional melanoma. Cytoplasmic melanin pigments are variably observed $[2,7]$. The nuclei of the spindle cells vary from oval to slender, with occasionally folded nuclear membrane. Intranuclear

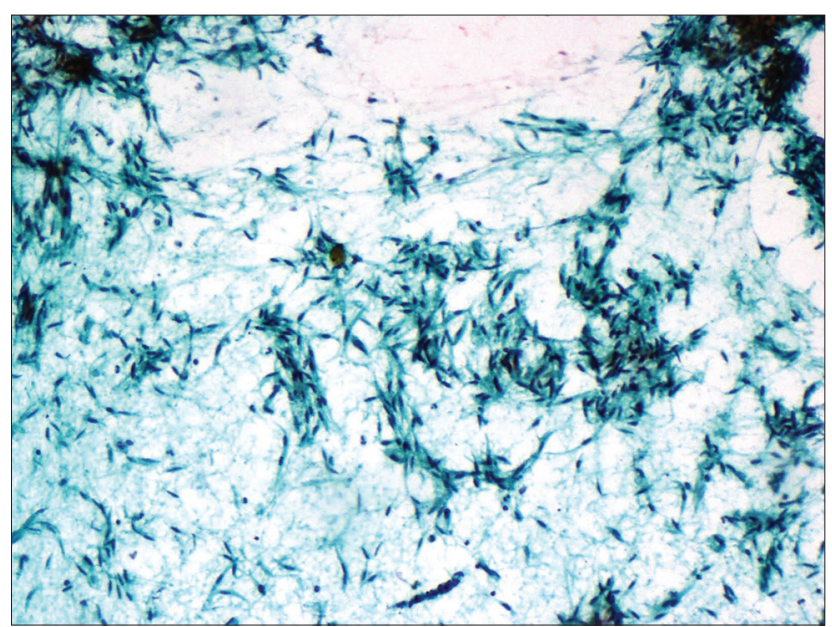

Figure 1: Clusters, fascicles and singly scattered spindle cells [Pap x40].

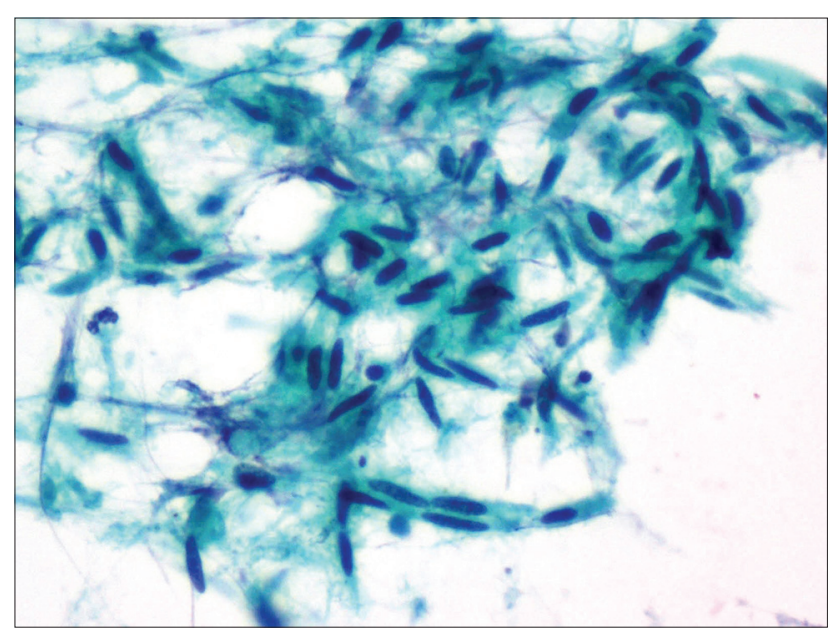

Figure 2: Spindle cells with elongated nuclei and scant cytoplasm [Pap x200]. pseudoinclusions are also variably noted. The chromatin is usually granular and delicate, nucleolus being inconspicuous and occasionally prominent $[6,8]$.

The spindle cells can also show varying degrees of cytological atypia, ranging from pleomorphic cells seen in high grade sarcomas to deceptively bland cells which resemble reactive fibroblasts $[9,10]$. The classic cytologic features of conventional melanoma which include predominantly dyscohesive clusters of cells, melanin pigments, intranuclear pseudoinclusions, eosinophilic macronucleoli, and binucleation or multinucleation are not frequently noted in spindle cell melanomas making the diagnosis more challenging and difficult (Table 1).

There are two distinct subtypes of malignant melanoma that differ clinic-pathologically and with respect to prognostic features. These include the spindle cell variant and desmoplastic melanoma $[2,3,11]$. Both these tumors show atypical, spindle malignant

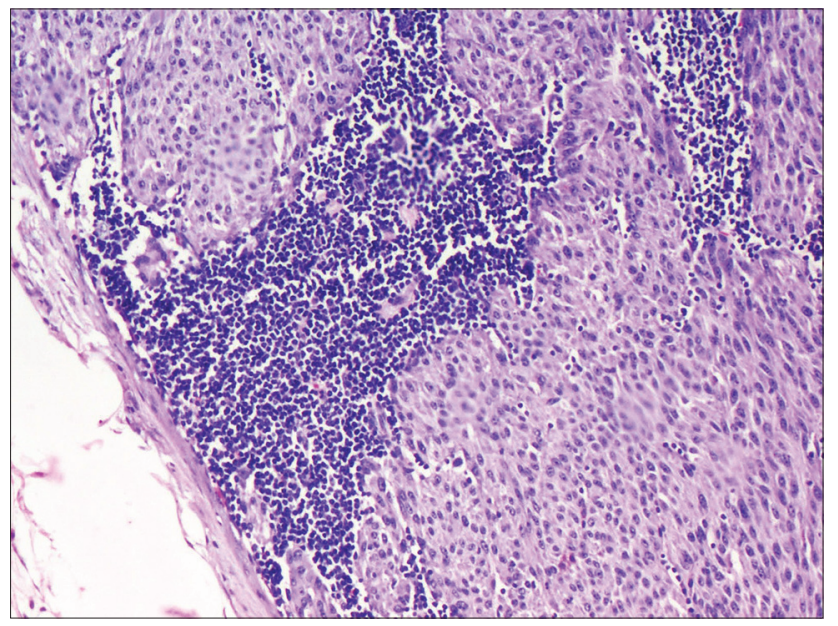

Figure 3: Lymphnode biopsy showing metastatic spindle cell melanoma [H \& E x40].

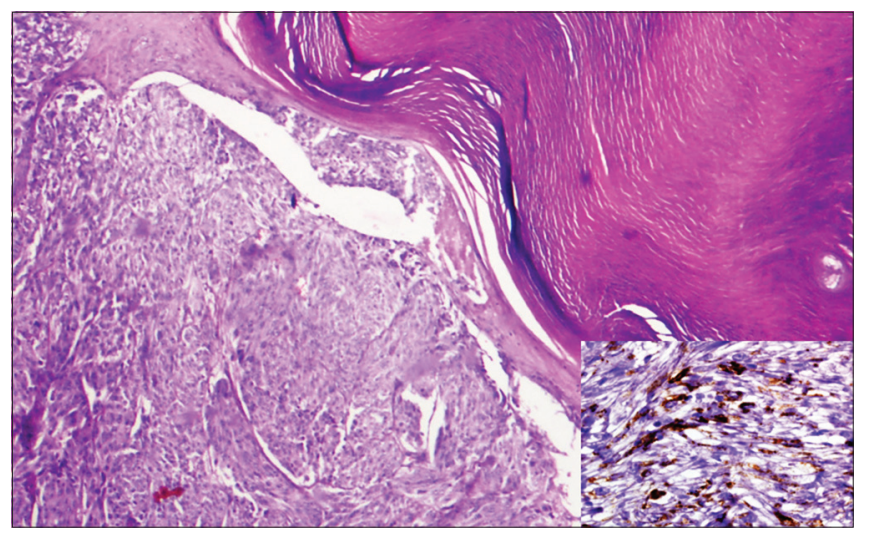

Figure 4: Skin lesion showing spindle cell melanoma. [H \& E x40]. Inset shows HMB 45 positivity. 
Table 1: Cytological findings of metastatic spindle cell melanoma compared with that of conventional melanoma

\begin{tabular}{lll}
\hline Cytological findings & Metastatic spindle cell melanoma & Metastatic conventional melanoma \\
\hline Cellularity & Cellular & Cellular \\
Architectural pattern & Predominantly interlacing fascicles and whorls of spindle cells & Predominantly dyscohesive clusters of polygonal cells \\
& Dyscohesive clusters also may be present & \\
& Few epitheloid cells clusters may be present & \\
Cytoplasmic melanin pigment & Variable & Usually present \\
Nuclear pleomorphism & Bland to highly pleomorphic & Highly pleomorphic \\
Nuclear pseudoinclusions & Rare & Usually present \\
Prominent macronucleoli & Rare & Present \\
Binucleate \& multinucleate cells & Absent & Present \\
\hline
\end{tabular}

Table 2: Differential diagnosis of spindle cell lesions

\begin{tabular}{|c|c|c|c|}
\hline Lesion & Age & Site & Cytological features \\
\hline $\begin{array}{l}\text { Spindle cell squamous cell } \\
\text { carcinoma }\end{array}$ & Elderly patients & $\begin{array}{l}\text { Sun exposed surfaces- plaque/ } \\
\text { tan to red nodule with ulcerated } \\
\text { surface }\end{array}$ & $\begin{array}{l}\text { Malignant spindled cells arranged in clucters or sheets with } \\
\text { pleomorphic nuclei, eosinophilic cytoplasm \& focal dyskeratotic } \\
\text { cells. }\end{array}$ \\
\hline $\begin{array}{l}\text { Cutaneous, subcutaneous \& deep } \\
\text { Leiomyosarcoma }\end{array}$ & Adult patients & Extremities-thigh & $\begin{array}{l}\text { Fascicular tissue fragments with moderate to scant cellularity, } \\
\text { nuclei may be uniform or pleomorphic, cigar-shaped with } \\
\text { abundant acidophilic or cyanophilic cytoplasm, characteristic } \\
\text { perinuclear vacuoles, mitotic figures. }\end{array}$ \\
\hline Dermatofibrosarcoma protruberans & Young adults & Trunk, proximal extremities, groin & $\begin{array}{l}\text { Tight clusters of bland spindle cells embedded in a collagenous/ } \\
\text { ibrillary and, often, metachromatic matrix along with dissociated, } \\
\text { uniform, or slightly atypical spindle cells or bare nuclei. }\end{array}$ \\
\hline Fibrosarcoma & Young adults & $\begin{array}{l}\text { Head and neck, lower extremities, } \\
\text { and the trunk }\end{array}$ & $\begin{array}{l}\text { Spindle cells arranged in bundles, nuclei are round to oval, } \\
\text { vesicular, moderate amount of tapering cytoplasm. Mitotic } \\
\text { figures may be abundant and may also single cells with } \\
\text { pleomorphic nuclei }\end{array}$ \\
\hline Synovial sarcoma & Young patients & Around joints & $\begin{array}{l}\text { Short, uniform spindle or epithelial cells with uniform vesicular } \\
\text { nuclei and micronucleoli. Gland formation in biphasic lesions is a } \\
\text { useful diagnostic feature. }\end{array}$ \\
\hline Atypical fibroxanthoma & $\begin{array}{l}\text { Elderly } \\
\text { Young adults }\end{array}$ & $\begin{array}{l}\text { Head or neck (elderly) } \\
\text { trunk, extremities (young adults) }\end{array}$ & $\begin{array}{l}\text { Plump spindle shaped cells with vesicular nucleus, arranged in } \\
\text { fascicles, large polyhedral cells, few being vacuolated; bizarre } \\
\text { giant cells (mononucleate or multinucleate) with hyperchromatic } \\
\text { nuclei. }\end{array}$ \\
\hline
\end{tabular}

melanocytes. In desmoplastic melanoma, these malignant cells are intimately admixed with ropy and dense collagen fibrils which was absent in the present case.

Other spindle cell lesions that fall into the differential diagnosis include atypical fibroxanthoma, cutaneous leiomyosarcoma, dermatofibrosarcoma protruberans, synovial sarcoma and spindle cell squamous cell carcinoma. However the clinical features of each of these entities differ and must be correlated with cytology findings (Table 2).

The immunohistochemical markers used to confirm a melanocytic nature include S-100, HMB-45, Melan-A, and MART-1, the latter 3 being relatively specific but less sensitive markers for melanomas. Loss of expression of these makers has also been noted in spindle cell melanomas and few of them aberrantly express cytokeratin $(10 \%)$ and smooth muscle actin $[2,3,8]$. In the present case HMB-45 was positive in the tumor cells.

\section{CONCLUSION}

Spindle cell melanoma may often be confused with other spindle cell lesions due to the lack of the characteristic features of conventional melanoma. A good clinical history is often helpful. FNAC is often used to document recurrent or metastatic disease and thus plays a very important role. Additional sources of diagnostic challenges, especially in the metastatic setting include varying degrees of cytologic atypia and possible cell type differences from the primary counterpart.

\section{ACKNOWLEDGEMENT}

We would kindly like to thank all the technical staff of the department of histopathology.

\section{CONSENT}

The examination of the patient was conducted according to the Declaration of Helsinki principles. 


\section{REFERENCES}

1. Weissinger SE, Keil P, Silvers DN, Klaus BM, Möller P, Horst BA, et al. A diagnostic algorithm to distinguish desmoplastic from spindle cell melanoma. Mod Pathol. 2014;27:524-34.

2. Maurichi A, Miceli R, Camerini T, Contiero P, Patuzzo R, Tragni G, et al. Pure desmoplastic melanoma: a melanoma with distinctive clinical behavior. Ann Surg. 2010;252:1052-7.

3. Walia R1, Jain D, Mathur SR, Iyer VK. Spindle cell melanoma: a comparison of the cytomorphological features with the epithelioid variant. Acta Cytol. 2013;57:557-61.

4. Piao Y, Guo M, Gong Y. Diagnostic challenges of metastatic spindle cell melanoma on fine-needle aspiration specimens. Cancer. 2008;114:94-101.

5. Leong SP, Gershenwald JE, Soong SJ, Schadendorf D, Tarhini AA, Agarwala S, et al. Cutaneous melanoma: a model to study cancer metastasis. J Surg Oncol. 2011;103:538-49.

6. Murali R, Doubrovsky A, Watson GF, McKenzie PR, Lee CS, McLeod DJ, et al Diagnosis of metastatic melanoma by fine-needle biopsy: analysis of 2,204 cases. Am J Clin Pathol. 2007;127:385-97.
7. Miller DD, Emley A, Yang S, Richards JE, Lee JE, Deng A, et al Mixed versus pure variants of desmoplastic melanoma: a genetic and immunohistochemical appraisal. Mod Pathol. 2011;25:505-5.

8. Murali R, Shaw HM, Lai K, McCarthy SW, Quinn MJ, Stretch JR, et al. Prognostic factors in cutaneous desmoplastic melanoma: a study of 252patients. Cancer. 2010;116:4130-8.

9. Dey P, Mallik MK, Gupta SK, Vasisht RK. Role of fine needle aspiration cytology in the diagnosis of tumors and tumor-like lesions. Cytopathology. 2004;15:32-7.

10. Loya A, Prayaga AK, Arora A, Sundaram C, Rao SI, Uppin SG, et al. Lymph node metastasis of soft tissue tumors: A cytomorphologic study. Acta Cytol. 200;51:153-60.

11. Mathur S, Kapila K, Verma K. Accuracy of cytologic grading of spindle cell sarcomas. Diagn Cytopathol. 2003;29:79-83.

Copyright by Archana Shivamurthy, et al. This is an open-access article distributed under the terms of the Creative Commons Attribution License, which permits unrestricted use, distribution, and reproduction in any medium, provided the original author and source are credited.

Source of Support: Nil, Conflict of Interest: None declared. 